\title{
Ultrastructural observations on the gills of polychaetes"
}

\author{
V.STORCH \& G. AlbERTI \\ Zoologisches Institut der Universität; \\ Hegerwiscbstr. 3, D-2300 Kiel, Federal Republic of Germany
}

\begin{abstract}
The gills of several polychaete species belonging to 9 families were studied by scanning and transmission electron microscopy. The surface epithelium is covered by a thin cuticle which is invaded by microvilli penetrating the epicuticle in certain species. Some epithelial cells bear cilia, others are mucus-producing cells. The ciliary cells may be arranged in rows and maintain a constant flow of water over the gills. The distance between external water and blood stream differs considerably according to the species investigated. In Malacoceros the gills are characterized by closed afferent and efferent subepithelial vessels, which correspond to tubular invaginations of the coelomic wall. These vessels are lined by the basement lamina of the coelothelial cells, which are of the epitheliomuscular type. The vessels are open in the gills of other polychaetes and release the blood stream into a system of spaces immediately below the epidermis (e.g. in the branchial lamellae of Pectinaria and Terebellides). In several species the blood comes into very intimate contact with the cuticle (e.g. in the gill filaments of Dendronereides), but also in these animals both are separated by a very small epidermal layer.
\end{abstract}

\section{INTRODUCTION}

In many polychaetes the exchange of gases takes place via the epidermis, special respiratory organs are absent. In some errant polychaetes and most sedentary forms, however, respiration is effected by gills or branchiae. The shape of these organs exhibits numerous types. In errant polychaetes they may consist of filiform appendages (among the genera investigated in this study e.g. in Ammotrypane), they may be pectinate (e.g. Eunice), bushy and branched (e.g. Dendronereides), or may consist of parallel lamellae (e.g. Pectinaria) to name only some genera (for reference see Hartmann-Schröder, 1971).

In the Errantia most body segments bear gills on the dorsal rami of many parapodia, in only some forms, however, they begin in some distance from the prostomium. The posterior segments usually lack gills. In the Sedentaria the gills are restricted to a small and often constant number of segments, normally situated in the anterior part of the body (e.g. in Terebellidae). Live observations show that gills of polychaetes can be very mobile and may function as pumps comparable to accessory hearts. Cilia often drive a water current over the gill surface.

\footnotetext{
* Supported by DFG Sto 75/3-6.
} 
In some cases it seems unlikely that the outgrowths of the body called gills in fact perform a significant respiratory function.

The tentacle crowns of Serpulimorpha and the numerous filiform tentacles of Terebellidae are mainly food collecting appendages. Presumably they have a respiratory function, too, at least in Serpulimorpha, but they are not dealt with in this publication.

The present investigation was undertaken in order to examine the ultrastructure of gill epithelia and blood vessels of primitive Articulata. Publications on the respiratory organs of arthropods, e.g. gills of Crustacea are abundant (see Storch \& Welsch, 1975), data on the fine structure of polychaete gills seem to be lacking. We investigated the ultrastructure of the genuine gills only, which are invaded by blood vessels. A second type of gills in polychaetes contains coelomic spaces and is destitute of blood capillaries, it has been neglected in this paper.

\section{MATERIALS AND METHODS}

The polychaetes used for the present investigation were collected mainly near Helgoland (North Sea), some species were obtained in the Baltic Sea, Dendronereides and Chloeia are from Belawan (North Sumatra, Straits of Malakka); Eunice is from the Mediterranean Sea.

Gills of the following species were studied electron microscopically: Chloeia flavit Pallas (Amphinomidae), Eunice torquata (Quatrefages) (Eunicidae), Scoloplos armiger (O. F. Müller) (Orbiniidae), Malacoceros fuliginosus (Claparède) (Spionidae), Scalibregma inflatum Rathke (Scalibregmidae), Ammotrypane aulogaster Rathke (Opheliidae), Pherusa plumosa (Müller) (Flabelligeridae), Pectinaria koreni (Malmgren) (Pectinariidae), Lanice concbilega (Pallas) (Terebellidae).

Whole gills and dissected parts were fixed in glutaraldehyde $(3.5 \%$ in phosphate buffer at $\mathrm{pH} 7.5)$. After postfixation in $\mathrm{OsO}_{4}(2 \%)$, these tissues were dehydrated in ethanol.

The specimens used for transmission electron microscopy were embedded in araldite. Thin sections were stained for 5 min with uranyl-acetate (saturated solution in $70 \%$ methanol), and for further $5 \mathrm{~min}$ with lead-citrate. Transmission electron microscopy was performed with a Zeiss EM 9 S-2.

The specimens used for scanning electron microscopy were dried using the critical point procedure, coated with gold and viewed in a Cambridge stereoscan S 4-10 microscope.

\section{RESULTS}

\section{Observations by scanning electron microscopy}

Polychaete gills usually are ciliated. The cilia are arranged in rows or in clusters (Fig. 1 a, c). Broad rows of cilia occur on the gills of Malacoceros fuliginosus and Sco- 


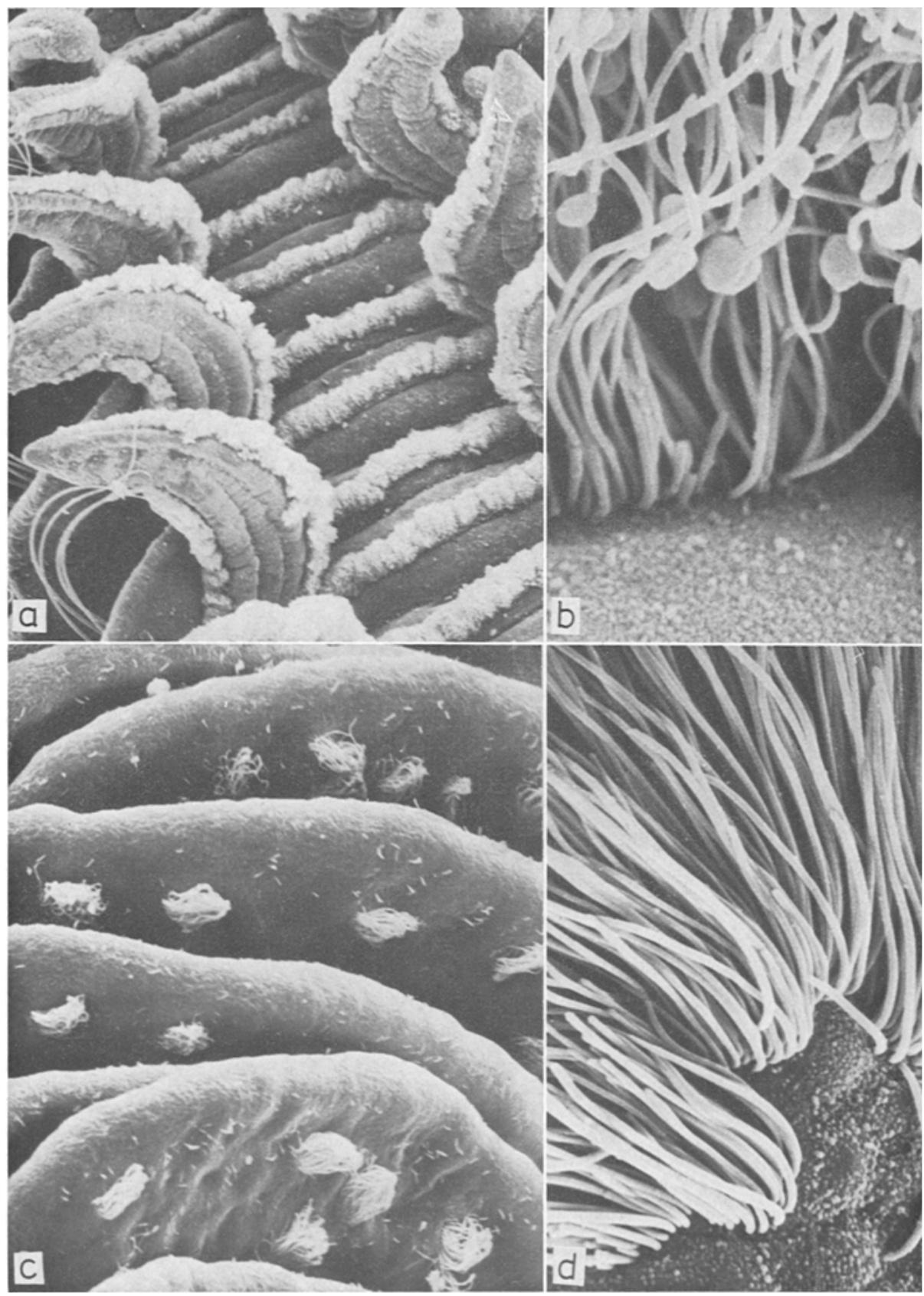

Fig. 1: Surface views of polychaete gills. (a) Malacoceros fuliginosus (70:1). (b) Malacoceros fuliginosus, paddle cilia $(5,500: 1)$. (c) Pectinaria koreni $(540: 1)$. (d) Terebellides stroemi $(3,200: 1)$ 
loplos armiger where they effect a continuous water current over the gill surface, smaller rows can be found on the gills of Ammotrypane aulogaster and Eunice torquata. Cilia arranged in clusters are typical for Pectinaria koreni (Fig. $1 \mathrm{c}$ ).

Scanning electron microscopy reveals that the gill cilia are of two different sorts: ordinary cilia and those bearing paddle-like, swellings (Fig. 1b, d). The first type is typical for the gills of Pherusa plumosa, Pectinaria koreni, and Terebellides stroemi, the second type is predominant on the respiratory organs of Malacoceros fuliginosus, Scoloplos armiger, Eunice torquata and Ammotrypane aulogaster. Often on the branchiae of Lanice conchilega clusters of cilia with a swollen tip resembling a bird's head were found.

\section{Observations by transmission electron microscopy}

According to transmission electron microscopical data the genuine gills of polychaetes can be classified as follows: (a) gills with true blood vessels bordered by epitheliomuscular cells (Fig. 2 a), (b) gills with partly opened vessels (Fig. 2 b), (c) gills with blood spaces directly below the surface epithelium which are not lined by coelothelial cells (Fig. 2 c), (d) gills with blood spaces within the surface epithelium. Larger and smaller filaments of embranched gills may show differences in their ultrastructure.

(a) In Malacoceros fuliginosus the epidermis of the gills consists of cubically shaped and columnar cells. The surface bears two rows of cilia the shafts of which have paddlelike enlargements (Fig. $1 \mathrm{a}, \mathrm{b}$ ). In their ultrastructure their shafts resemble those which have recently been described by Berquist et al. (1977) from sponge larvae and by Dilly (1977) in Rbabdopleura. The rootlets of these cilia are extremely long and show a distinct cross striation. The cytoplasm of the ciliated cells contains large amounts of densely packed mitochondria (Fig. 3 a). Nerve endings occur very frequently at their bases. In addition to these ciliated cells normal epidermis cells (supportive cells) and secretory cells occur. The secretory cells contain large quantities of rough endoplasmic reticulum and Golgi fields and light secretory droplets. The epithelium is underlain by collagen fibrils. In the core of the gills one afferent and one efferent blood vessel occur. They represent tubular invaginations of an outgrowth of the coelomic cavity (Fig. 2 a) and are lined by the basement lamina of the coelothelium which consists of epitheliomuscular cells (Fig. 3 c). An endothelium is absent. The exchange of gases thus is performed through the following layers (from the centre to the periphery): epitheliomuscular cells bordering the vessels (= visceral layer of the coelothelium), coelomic space of the gill, parietal layer of the coelomic lining, subepidermal collagen layer, epidermis and cuticle.

(b) In different species investigated the blood does not circulate in tubular vessels but in spaces which are irregularly shaped in cross sections. Distally they are lined by the basement lamina of the epidermis and proximally by the basement lamina of the coelothelium (Fig. 2 b). The gill epidermis covering the blood spaces is rather thick in some cases (e.g. Scoloplos armiger), in other species it may be comparatively thin in certain areas (Ammotrypane aulogaster). In Ammotrypane aulogaster on one side of 

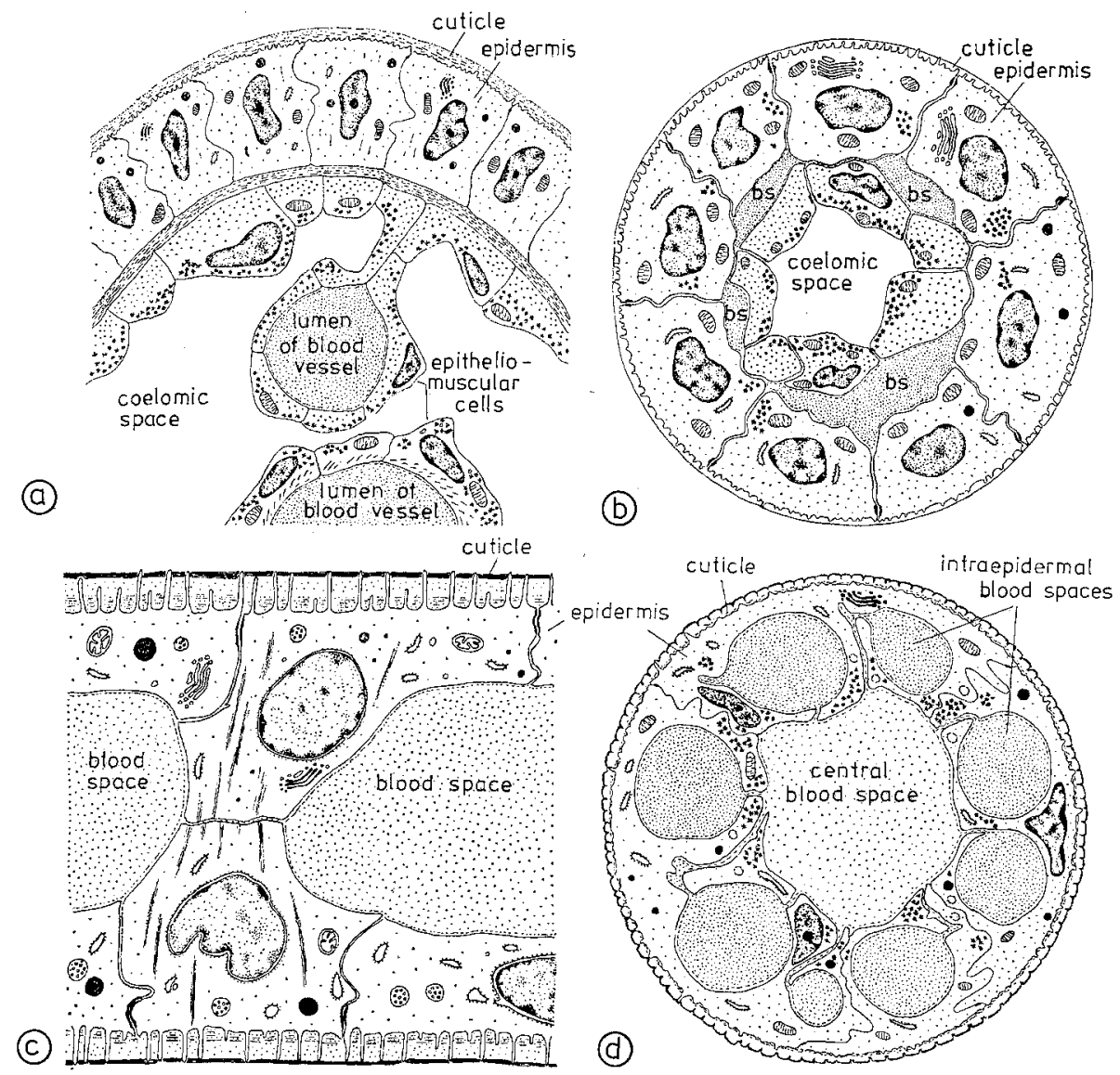

Fig. 2: Diagrams of different types of polychaete gills. (a) Malacoceros fuliginosus; (b) Scalibregma inflatum, bs: blood space; (c) Pectinaria koreni; (d) Dendronereides beteropoda

the gills opposite to the largest blood space numerous mucus cells with varied inclusions occur.

(c) The gill leaflets of Pectinaria koreni consist of cuboidal to flattened epithelial cells and subepidermal blood spaces (Fig. 2 c, 4 a). They lack a coelomic epithelium. In certain areas the epidermal cells of opposing gill walls are attached to each other (Fig. 2 c, 4 a). They resemble the pillar-cells of the gills of Crustacea and are characterized by bundles of tonofilaments. The other cells are characterized by their paucity of organells (mitochondria, rough endoplasmic reticulum, Golgi fields, multivesicular bodies). The interspersed ciliary cells possess many mitochondria. At their bases nerve endings can be found. The nearly homogeneous cuticie is thin and penetrated by microvilli. The gills of Terebellides stroemi exhibit a similar ultrastructure. Their epidermis which is characterized by a high microvillous border can be very thin (Fig. 3 b). In the branchiae of Scalibregma inflatum and Lanice conchilega the gill filaments of a very 


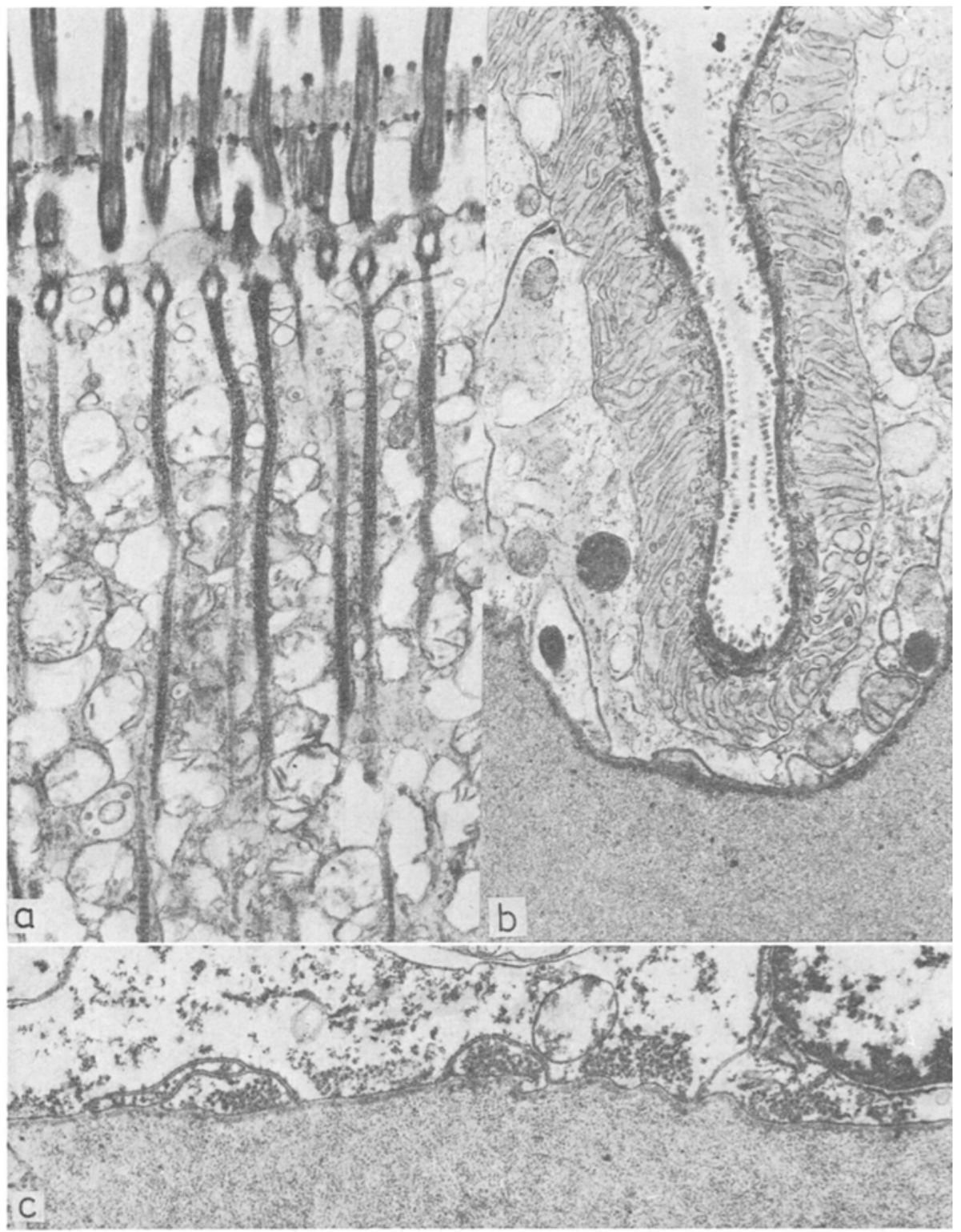

Fig. 3: (a) Ciliated cell of the gill of Malacoceros fuliginosus (14,300:1). (b) Flattened surface epithelium with microvillous border of Terebellides stroemi (16,700:1). (c) Epitheliomuscular cells and blood space of Malacoceros fuliginosus (14,300:1) 


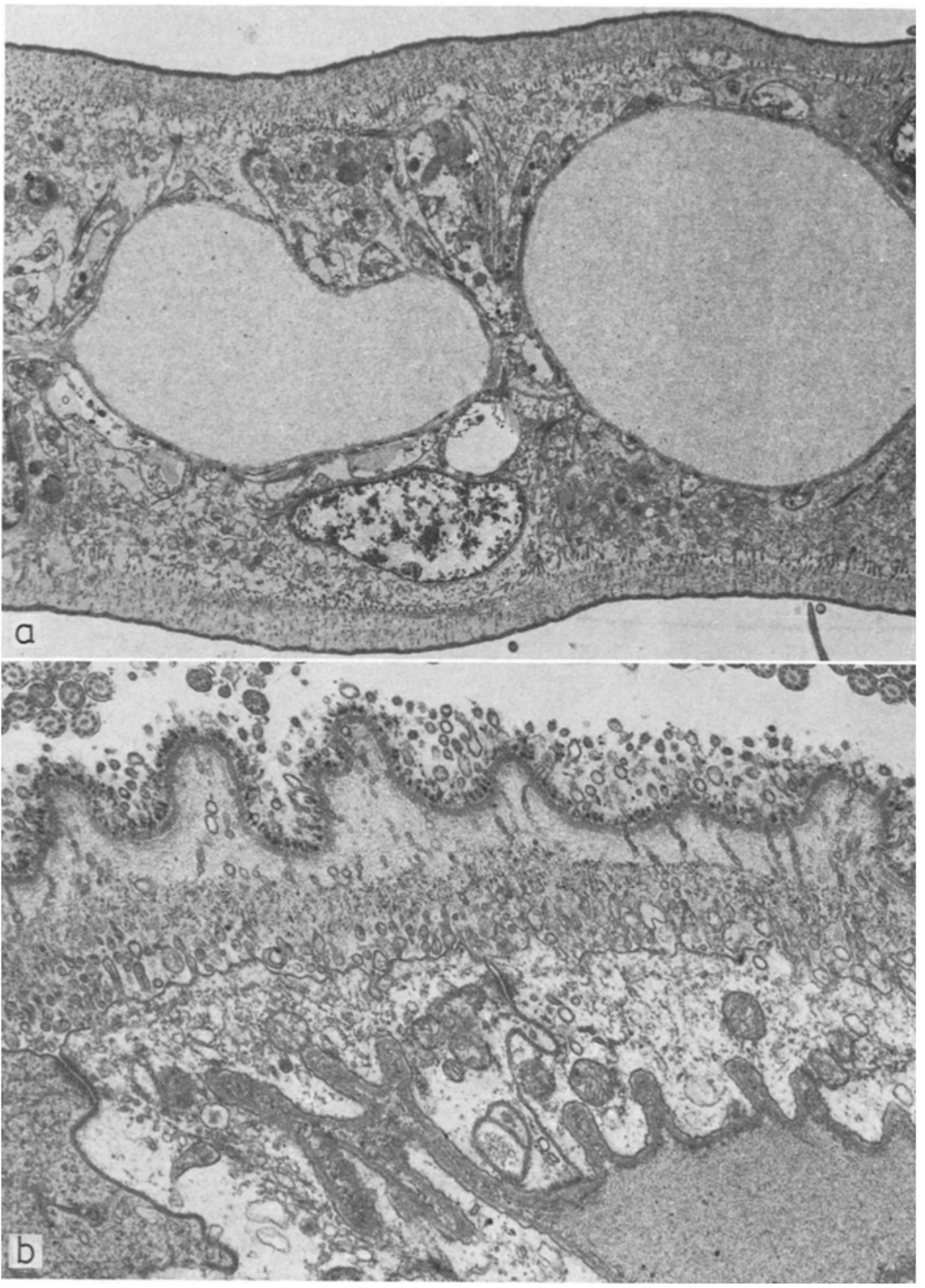

Fig. 4: (a) Cross-section of a gill leaflet of Pectinaria koreni $(5,000: 1)$. (b) Intraepidermal blood space near the epidermal apex of Pherusa plumosa $(14,300: 1)$ 
small caliber only consist of epidermis and a central blood space, the medium sized branches contain some single muscel cells within the blood space which are attached to the basement lamina of the epidermis cells, the large branches contain an outgrowth of the coelomic cavity.

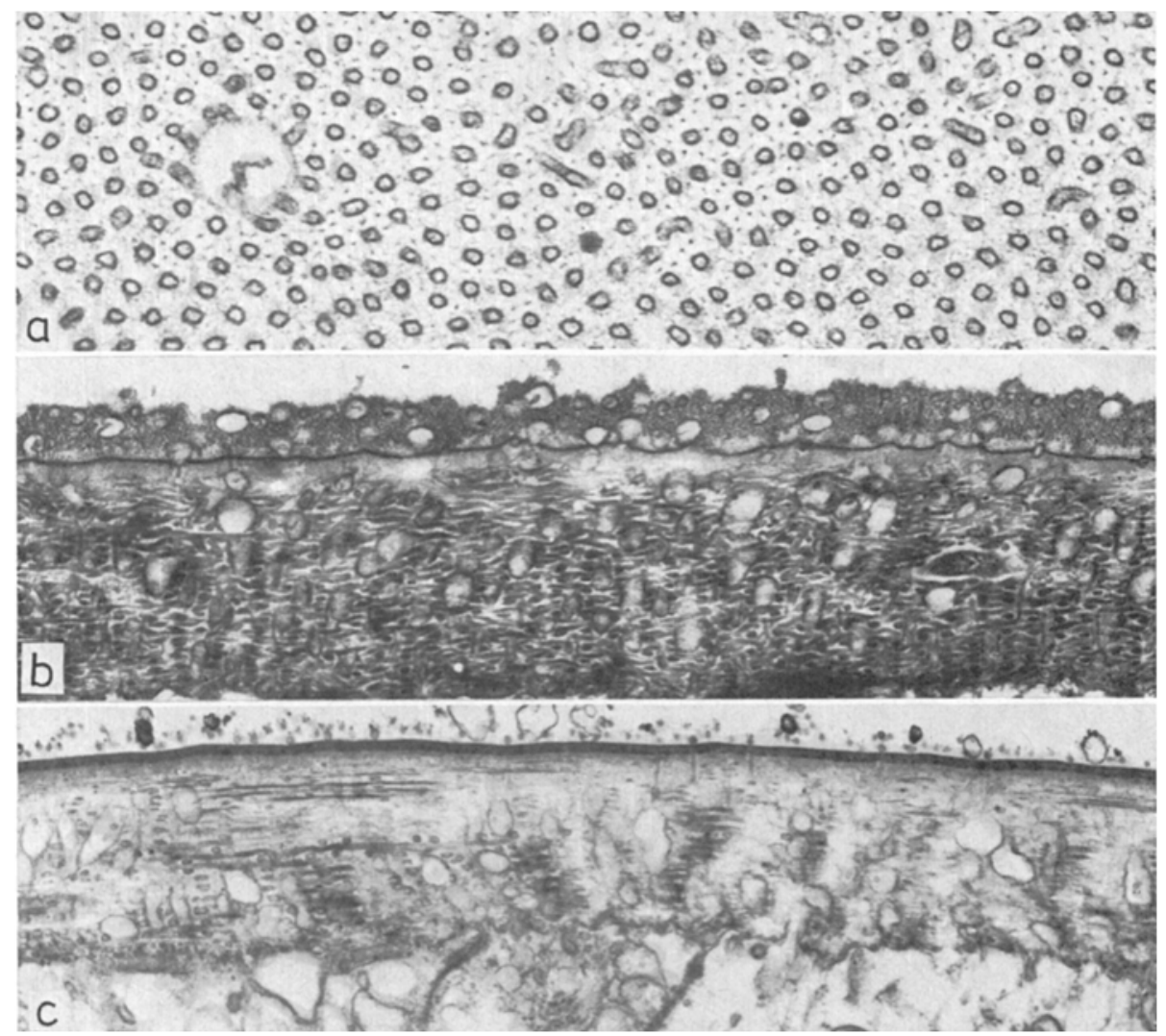

Fig. 5: Microvillous border and cuticle of polychaete gills. (a) Microvilli penetrating the cuticle of Chloeia flava in cross-section $(28,500: 1)$. (b) Cuticle of Eunice torquata (14,300:1). (c) Cuticle of Ammotrypane aulogaster (14,300:1)

(d) On cross-sections of the gill filaments of Dendronereides beteropoda eight to twelve roundish blood spaces can be detected bulging deeply into the epidermis (Fig. 2 d). However, they always remain separated from the epidermal cells by a basement lamina. They are surrounded by thin laminar processes of one or more epidermal cells. These blood spaces are connected by very narrow channels with a central space devoid of musculature and coelomic epithelium.

These infoldings reaching into the epidermis are of wide distribution within the group of polychaetes. They are sometimes regularly arranged as in Dendronereides beteropoda or can occur in irregular distribution as in Eunice torquata, Pherusa plumosa 
(Fig. 4 b), Lanice conchilega. In cross-sections they can be roundish (Dendronereides beteropoda), pearshaped (Chloeia flava, Lanice conchilega), or sometimes they are very narrow (Lanice conchilega). The distance between water and blood in this case is reduced to a minimum. The blood stream in these species nearly reaches the cuticle. The infoldings into the epidermis may occur in some cases in gill types b and c, too (e.g. Scalibregma inflatum).

The epidermis and the cuticular layer of the gills (Fig. 5), apart from a reduced diameter, in general resemble the normal integument of the body and its appendages, as has been described in several publications (see Storch \& Welsch, 1972 b). Special cell types have not been found apart from mucus cells and receptor cells which are also known from other regions of the body in the same manner (see Storch, 1972; Storch $\&$ Welsch, 1972 a).

\section{DISCUSSION}

In recent years the respiratory function of polychaete blood has been studied in great detail (e.g. Ochi, 1969; Terwilliger, 1974; Economides \& Wells, 1975; Mangum et al., 1975; Wells \& Warren, 1975). Origin and importance of the diversity of tetrapyrrole pigments have been elucidated by Mangum \& Dales (1965). Recent morphological data of the respiratory organs, however, are lacking, and even representations of the circulatory systems of preferred objects in respiratory physiology are usually based on older light microscopical descriptions (Mangum, 1976).

The present study has shown that the branchiae of polychaetes are really true respiratory organs and that they differ in this respect from the gills of some other animal phyla where these organs perform both respiratory functions and ion absorption [e.g. in Crustacea (see Storch \& Welsch, 1975; Bubel, 1976), insects (Greven \& Rudolph, 1973) and fishes (see Welsch \& Storch, 1976)]. Fine structural details reminiscent of transporting epithelia have not been detected in the polychaete gills so far investigated. In regular echinoids the term gill would even appear inappropriate since most respiratory function is via the tube feet (Cobb \& Sneddon, 1977).

According to our ultrastructural results there is good reason to believe that in different species the branchiae are of very different importance for the gas exchange, for the distance between blood stream and sea water differs considerably. In Malacoceros fuliginosus the afferent and efferent blood vessels are closed, their separate cores of flow are clearly recognizable in living specimens. The blood vessels correspond to a primitive type according to Remane (1950).

Their wall is formed by epitheliomuscular cells the basal lamina of which faces the blood space. Similar blood vessels have recently been described in Tentaculata (Welsch \& Storch, 1976; Reed \& Cloney, 1977).

In other cases the coelomic cavity, normally penetrating into many appendages of polychaetes (see Orrhage, 1964, and Siewing, 1976, for details), has been retracted. Here the blood vessels are no longer tubular channels, but open out in the direction of the epidermis. In this type of our classification (Fig. 1 b) and in type $c$ the blood reaches 
the bases of the epidermis. If these gills have to be regarded as a set of blind ending tubes (Mangum, 1976) cannot be decided.

In any case, the greatest possible reduction of the distance between blood and water can be observed in type $d$. This kind of branchiae occurs in Dendronereides beteropoda belonging to the family of Nereidae which normally lacks gills (Gravier, 1934).

Future studies will have to show if the types of gills described in this paper are of different effectiveness or if they can be correlated with the survival of polychaetes in low dissolved oxygen environments (Reish, 1966).

Acknowledgements. We would like to thank the Biologische Anstalt Helgoland for laboratory space and support. Mr. K. Graeber provided us with skilfully prepared material of Eunice.

\section{LITERATURE CITED}

Berquist, P. R., Green, C. R., Sinclair, M. E. \& Roberts, H. S., 1977. The morphology of cilia in sponge larvae. Tiss. Cell 9, 179-184.

Bubel, A., 1976. Histological and electron microscopical observations on the effects of different salinities and heavy metal ions, on the gills of Jaera nordmanni (Rathke) (Crustacea, Isopoda). Cell Tiss. Res. 167, 65-95.

Cobb, J. L. S. \& Sneddon, E., 1977. An ultrastructural study on the gills of Echinus esculentus. Cell Tiss. Res. 182, 265-274.

Dilly, P. N., 1977. Further observations of transport within paddle cilia. Cell Tiss. Res. 185, 105-113.

Economides, A. P. \& Wells, R. M. G., 1975. The respiratory function of the blood of Neanthes (= Nereis) virens (Sars) (Polychaeta: Nereidae). Comp. Biochem. Physiol. 51, 219-223.

Gravier, Ch., 1934. Remarques sur la morphologie du parapode des Néréidiens. Annls. Sci. nat. 17, 347-367.

Greven, H. \& Rudolph, R., 1973. Histologie und Feinstruktur der larvalen Kiemenkammer von Aeshna cyanea (Odonata: Anisoptera). Z. Morph. Tiere 76, 209-226.

Hartmann-Schröder, G., 1971. Polychaeta. Tierwelt Dtl. 58, 1-594.

Mangum, Ch. P. \& Dales, R. Ph., 1965. Products of haem synthesis in polychaetes. Comp. Biochem. Physiol. 15, 237-357.

Mangum, Ch. P., Woodin, B. R., Bonaventura, C., Sullivan, B. \& Bonaventura, J., 1975. The role of coelomic and vascular hemoglobin in the annelid family Terebellidae. Comp. Biochem. Physiol. 51, 281-294.

Mangum, Ch. P., 1976. The oxygenation of hemoglobin in lugworms. Physiol. Zool. 49, 85-99.

Ochi, O., 1969. Blood pigments and erythrocytes found in some marine Annelida. Mem. Ehine Univ. Sc. (Biol.) 6, 63-131.

Orrhage, L., 1964. Anatomische und morphologische Studien über die Polychaetenfamilien Spionidae, Disomidae und Poecilochaetidae. Zoolog. Bidr. Uppsala 36, 335-405.

Reed, Ch. C. \& Cloney, R. A., 1977. Brachiopod tentacles: Ultrastructure and functional significance of the connective tissue and myoepithelial cells in Terebratalia. Cell Tiss. Res. 185, $17-42$.

Reish, D. J., 1966. Relationship of polychaetes to varying dissolved oxygen concentrations. In: Avances in water pollution research. 3rd international conference on water pollution research, Sect. 3, 1-10.

Remane, A., 1950. Die Entstehung der Metamerie der Wirbellosen. Verh. dt. zool. Ges. 1949, 16-23. 
Siewing, R., 1976. Probleme und neuere Erkenntnisse in der Großsystematik der Wirbellosen. Verh. dt. zool. Ges. 69, 59-83.

Storch, V., 1972. Elektronenmikroskopische Untersuchungen an Receptoren von Anneliden (Polychaeta, Oligochaeta). Z. mikrosk.-anat. Forsch. 85, 55-84.

- \& Welsch, U., 1972a. The ultrastructure of epidermal mucous cells in marine invertebrates (Nemertini, Polychaeta, Prosobranchia, Opisthobranchia). Mar. Biol. 13, 167-175.

- - 1972b. Ultrastructure and histochemistry of the integument of air-breathing polychaetes from mangrove-swamps of Sumatra. Mar. Biol. 17, 137-144.

- - 1975. Über Bau und Funktion der Kiemen und Lungen von Ocypode ceratophthalma (Decapoda: Crustacea). Mar. Biol. 29, 363-371.

Terwilliger, R. C., 1974. Oxygen equilibria of the vascular and coelomic hemoglobins of the terebellid polychaete, Pista pacifica. Evidence for an oxygen transfer system. Comp. Biochem. Physiol. 48 A, 745-755.

Wells, R. M. G. \& Warren, L. M., 1975. The Function of the cellular haemoglobins in Capitella capitata (Fabricius) and Notomastus latericeus Sars (Capitellidae: Polychaeta). Comp. Biochem. Physiol. 51 A, 737-740.

Welsch, U. \& Storch, V., 1976a. Comparative animal cytology and histology. Sidgwick \& Jackson, London, $343 \mathrm{pp}$.

- - 1976b. Elektronenmikroskopische Beobachtungen am Kiemenepithel des amphibischen Teleosteers Periophthalmus vulgaris. Z. mikrosk.-anat. Forsch. 90, 447-457. 